\title{
Identification of Acinetobacter baumannii and Determination of MDR and XDR Strains
}

\author{
Noor Hussein Ahmad ${ }^{1 *}$
}

Ghada A. Mohammad ${ }^{2}$

\author{
${ }^{1}$ Medical laboratory technology Department, Al-Noor University College, Ninawa, Iraq. \\ ${ }^{2}$ Department of Biology, College of Science, University of Mosul, Mosul, Iraq. \\ *Corresponding author: *noor.hussain@alnoor.edu.iq, Kadsbio32@uomosul.edu.iq \\ *ORCID ID: *https://orcid.org/0000-0001-9188-5657, https://orcid.org/0000-0003-1298-3350
}

Received 4/11/2018, Accepted 11/6/2019, Published 1/9/2020

This work is licensed under a Creative Commons Attribution 4.0 International License.

\begin{abstract}
:
The current study focuses on the bacterium Acinetobacter baumannii due to its importance as a nosocomial infections source in addition to its increased resistance against antibiotics. Different clinical and hospital environment samples were collected, and cultured on A. baumannii selective media: Leed Acinetobacter agar and Herellea agar. A. baumannii have been identified by traditional methods, followed by confirmation using molecular identification to detect bla $\mathrm{axa}_{51}$ like gene which is considered a diagnostic gene since it is present in genome of all A. baumannii strains. The result was, nineteen bacterial isolates of A.baumannii were obtained, from twenty-seven suspected isolates, detection of local isolates belonging to MDR or XDR group. Results demonstrated that all local isolates are MDR and 16 isolates (84.2\%) are XDR.
\end{abstract}

Key words: Acinetobacter baumannii, bla ${ }_{\text {oxa-5l }}$ gene, MDR, XDR.

\section{Introduction:}

Acinetobacter baumannii (A. baumannii) is a gram negative bacteria, sometimes diagnosed as gram positive due to its resistance to alcohol when stained with gram stain, strict aerobic, non-motile but has some sort of twitching motility by polar fimbriae.

Oxidase negative, catalase positive, indole negative, positive for citrate with $\mathrm{C} / \mathrm{G}$ content 47$39 \%$, non-lactose fermenter, the optimum temperature for their growth is $33-35^{\circ} \mathrm{C}$, many strains are nitrate negative and do not form spores They are easy to grow on the non-fastidious culture media $(1,2)$

A.baumannii bacteria have been of increasing importance for several reasons: they cause hospital infections and are responsible for $2-10 \%$ of all hospital-related infections of gram-negative bacteria, like septicemia, meningitis, UTI and others. They are an opportunistic pathogen, as well as for the acquisition of multi drug-resistant (MDR) and extensive drug-resistant (XDR) (3). This bacterium is resistant to many antibiotics, including aminoglycosides, tetracyclines, cephalosporins, ampicillins, cefotaximes, chloramphenicol, gentamycin, tobramycines, quinolones and marcolides $(4,5)$.
The main cause of A.baumannii infections is due to: speed in transformation, rapid development in resisting a wide range of antibiotics such as efflux pumps system and horizontal gene transfer, and prevalence in the dry environment of hospitals for long periods of time (6).

This study aims to investigate the prevalence of A.baumannii isolates by implementing special selective media, identification by conventional methods followed by detection of the bla oxa-5l gene (diagnostic gene for A.baumannii because it is present in the genome of all its isolates ), and that delimiting MDR and XDR A.baumannii isolates.

\section{Materials and Methods:}

Sampling: A total of 233 samples were collected from hospitals in Mosul (Al Salam Teaching Hospital, Al Khansaa Hospital, Ibn Al Athir Children's Hospital, Al-Gomhouri teaching Hospital) during the period from August 2017 to January 2018 (According to Ministry of Health Book No. 10397 dated 7/19/2017). The samples included: 166 specimens, from wounds, urine, respiratory infections(sputum), burns, CSF and 67 samples from the hospital environment(swabs), 
including samples from intensive care unit, patient beds, surgical instruments and appliances, emergency lobby and baby incubators.

The specimens were transferred to the laboratory (by transport media) and cultured on selective A. baumannii media (Leed Acinetobacter medium (LAM) and Herellea agar medium) prepared according to $(7,8)$. As well as blood agar and MacConkey agar then incubated at $37^{\circ} \mathrm{C}$ for 24 hours under aerobic conditions.

\section{Identification:}

\section{Cultural characteristics and microscopy:}

The cells were examined microscopically to observe the staining reaction and cells arrangement.

Biochemical tests: The following tests were carried on: oxidase test, urease test, motility test, oxidation-fermentation test (O-F test), catalase test, IMViC test (indole production test, methyl red test, voges -proskauer test, citrate utilization test), triple sugar iron Agar, carbohydrate fermentation test. these tests prepared according to $(9,10)$.

Diagnosis using the Analytical Profile Index System (API 20E): It is a multi-test system that is clinically used for the rapid diagnosis of Enterobacteriaceae and other Gram negative bacteria and includes 20 tests arranged in a special strip.The test is conducted according to the instructions of the French manufacturer BioMerieux.

The diagnosis has been done using the API$20 \mathrm{E}$ system, which is an accurate test for the diagnosis of bacterial species. After 24 hours of incubation, the necessary reagents were added, positive and negative results were recorded and seven numbers (codes) were recorded.

Molecular identification: Standard strain of $A$. baumannii ATCC 19606 was obtained from Media center in Irbil government.

- DNA Extraction: Bacterial DNA was extracted from $A$. baumanniii using the boiling method by (11).

- Determination of concentration and purity of extracted DNA: to confirm the presence of DNA in our isolate,the concentration and purity of DNA extracted from the bacterial isolates of $A$. baumannii was measured by the Nanodrop device at the Research Laboratory of the Department of Life Sciences / College of Science.

- PCR amplification: PCR reactions was conducted to confirm the diagnosis of samples using the bla oxa-51 gene.Using the bla oxa-51 primers of the USA Alpha Company, the primer has a molecular size of 353 base pairs and consists of sequences:

bla ${ }_{\text {OXA51 }}$ F:5`TAATGCTTTGATCGGCCTTG 3 bla OXA51 R:3 TGGATTGCACTTCATCTTGG 5 PCR mixture was prepared as the total size 25 microliters, $4 \mu \mathrm{L}$ DNA $(50 \mu \mathrm{L})$, primers $(10$ picomol), $6.5 \mu \mathrm{L}$ Premix $(2 \mathrm{x})$ and $12.5 \mu \mathrm{L}$ Deionized water.

The previous prepared mixture was placed in thermal cycler, and the program was run as suggested by (11) : $94^{\circ} \mathrm{C}$ for $5 \mathrm{~min} ., 94^{\circ} \mathrm{C}$ for $30 \mathrm{sec}$., $55^{\circ} \mathrm{C}$ for $30 \mathrm{sec}$, $72^{\circ} \mathrm{C}$ for $90 \mathrm{sec}$ ( 30 Cycles), $72^{\circ} \mathrm{C}$ for $7 \mathrm{~min}$.

Investigation of MDR and XDR isolates: The determination of MDR and XDR of A. baumannii local isolates was carried out by antibiotics susceptibility test (disc diffusion method) depending on (Kirby \& Bauer 1966) using Mueller Hinton agar, and the antibiotics discs used were supplied from Mast English company, AmpicillinSulbactam $20 \mu \mathrm{g} / \mathrm{disc}$, Meropenem $10 \mu \mathrm{g} / \mathrm{disc}$, Cefetriaxone $30 \mu \mathrm{g} / \mathrm{disc}$, Azithromycin $15 \mu \mathrm{g} / \mathrm{disc}$, Erythromycin $15 \mu \mathrm{g} /$ disc, Clarithromycin $15 \mu \mathrm{g} /$ disc, Nalidixic acid $30 \mu \mathrm{g} / \mathrm{disc}$, Trimethoprime 5 $\mu \mathrm{g} / \mathrm{disc}$, Levofloxacine $5 \mu \mathrm{g} / \mathrm{disc}$, Ciprofloxacine 5 $\mu \mathrm{g} / \mathrm{disc}$, Amikacin $30 \mu \mathrm{g} / \mathrm{disc}$, Gentamicin $10 \mu \mathrm{g} /$ disc, Tobramycin $10 \mu \mathrm{g} /$ disc, Tetracycline $30 \mu \mathrm{g} /$ disc, Doxycycline $30 \mu \mathrm{g} / \mathrm{disc}$,

\section{Results and Discussion: \\ Morphological result:}

After taking the samples to the laboratory, they were cultured on A. baumannii selective media, the colonies of this bacteria on Leed Acinetobacter agar(LAM) showed a convex circular shape with smooth transluscent opaque with smooth edges of 1-2 mm diameter and pink color with pink to red background after 24 hours of incubation at $37^{\circ} \mathrm{C}$ (Fig. 1). The transformation of the color of the medium to red is due to the high alkali produced in the medium by the release of ammonium ions from complex nitrogen compounds in the medium. A.baumannii produces alkaline compounds when sucrose and fructose are consumed in the medium making the color of the medium red $(9,12)$.

A.baumannii colonies on the Herellea agar (Fig. 2) were round with smooth margins of 2-3 mm in the form of pale lavender flower, this is similar to what is described by $(7,8)$.

While colonies on MacConkey agar were pale, round and with a diameter of 2-3 $\mathrm{mm}$ because it is non- lactose fermenter and turned pink after 48 hours of incubation as in Fig. (3), and this description is consistent with (1). On blood agar, colonies were convex, gray or white color. It does 
not lyse blood because it does not producing the enzyme hemolysin as shown in the Fig. (4).

Other isolates were obtained in our study such as: pseudomonase aeruginosa (11.3\%), E.coli (7.7\%), Klebsiella pneumonia (7.2\%), Proteus vulgaris $(6 \%)$ and Serratia liquefaciens (3.8\%).

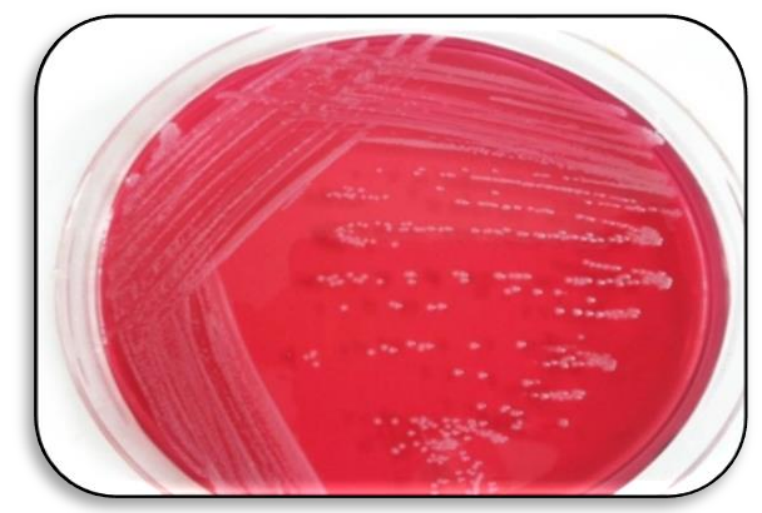

Figure 1. A.baumannii colonies on LAM.

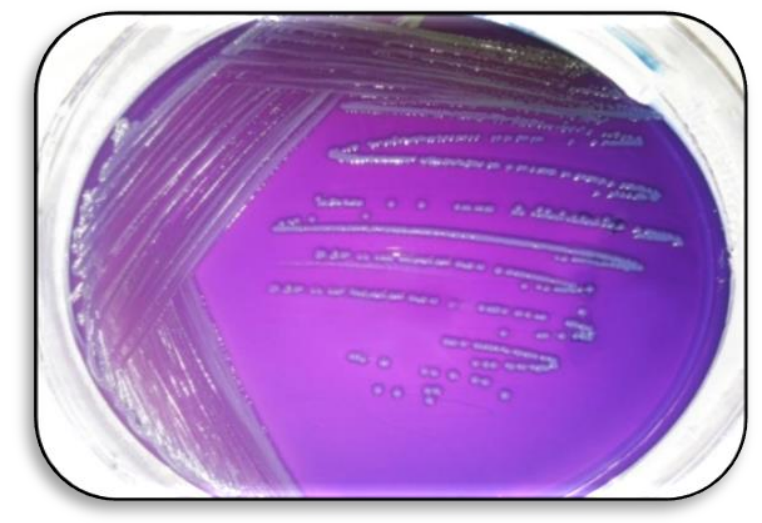

Figure 2. A.baumannii colonies on Herellea agar.

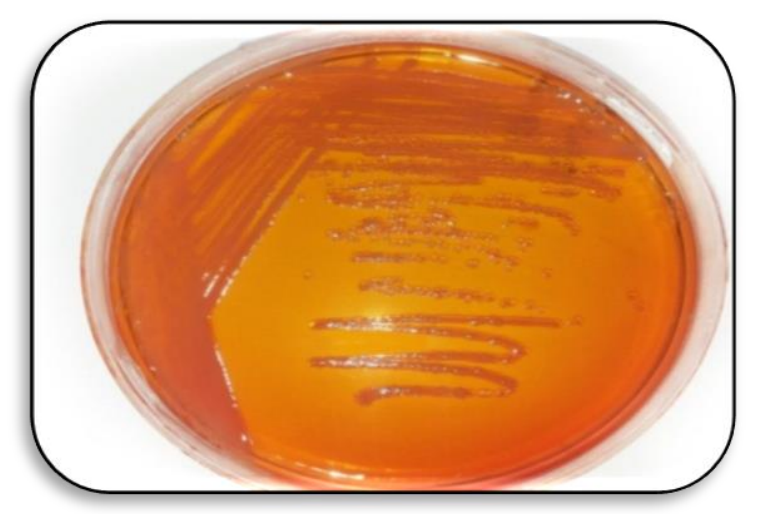

Figure 3. A.baumannii colonies on MacConkey agar.

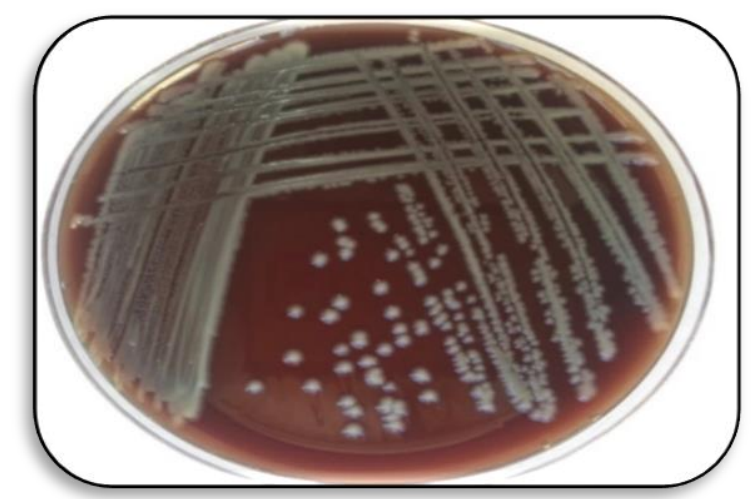

Figure 4. A.baumannii colonies on blood agar.

The microscopic examination of the bacterial smears showed gram negative coccobacilli, it may appear positive for gram because it is alcoholresistant, and may be single or sometimes diplo (2).

\section{Biochemical tests}

The results of biochemical tests for identification of A. baumannii are shown in Table (1).

Table 1. Biochemical test results for A. baumanii

\begin{tabular}{lll}
\hline Biochemical test & Result \\
\hline Oxidase test & & - \\
Urease test & & + \\
O-F Test & & - \\
Motility test & & + \\
Catalase test & & ---+ \\
IMVIC & & $\mathrm{K} / \mathrm{K}, \mathrm{H}_{2} \mathrm{~S}-$ \\
Triple sugar iron & agar test (TSI) & + \\
& Glucose & - \\
& Sucrose & - \\
Sugar & Maltose & - \\
fermentation & Rabinoz & Galactose \\
test & Lactose & - \\
& Fructose & - \\
& Sorbitol & - \\
\hline
\end{tabular}

Diagnosis with API-20E:

The code was entered into the analytical profile index to find out the full scientific name for bacterial isolation, as in Fig.5. 


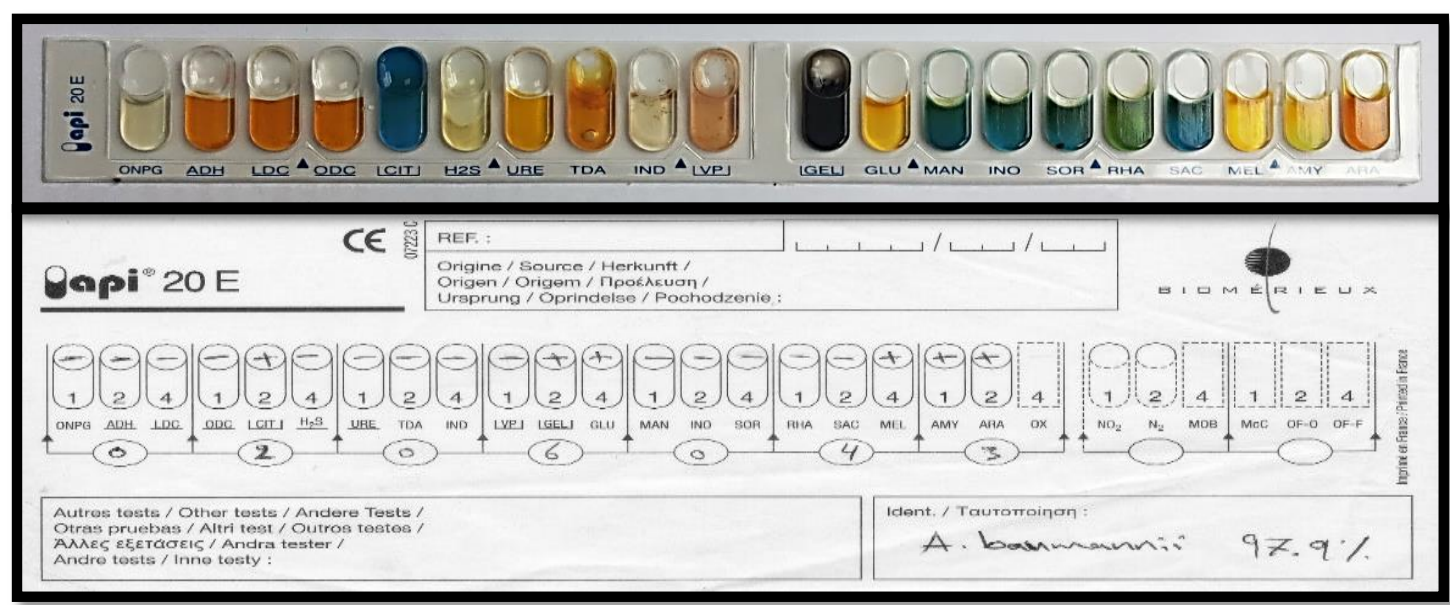

Figure 5. Result of Acinetobacter baumannii test by API-20E strip

Molecular diagnosis of isolates using the $b l a_{\text {oxa-51 }}$ like gene

After conducting the routine and API-20E identification, twenty-seven suspected isolates of A.baumannii have been obtained, conformation of these isolates by PCR, the result shows that 19 isolates of A.baumannii were obtained, whereby the appeared band by our isolates were compared by the band of a standard strain A.baumannii ATCC 19606 as shown in Fig. 6, 7.

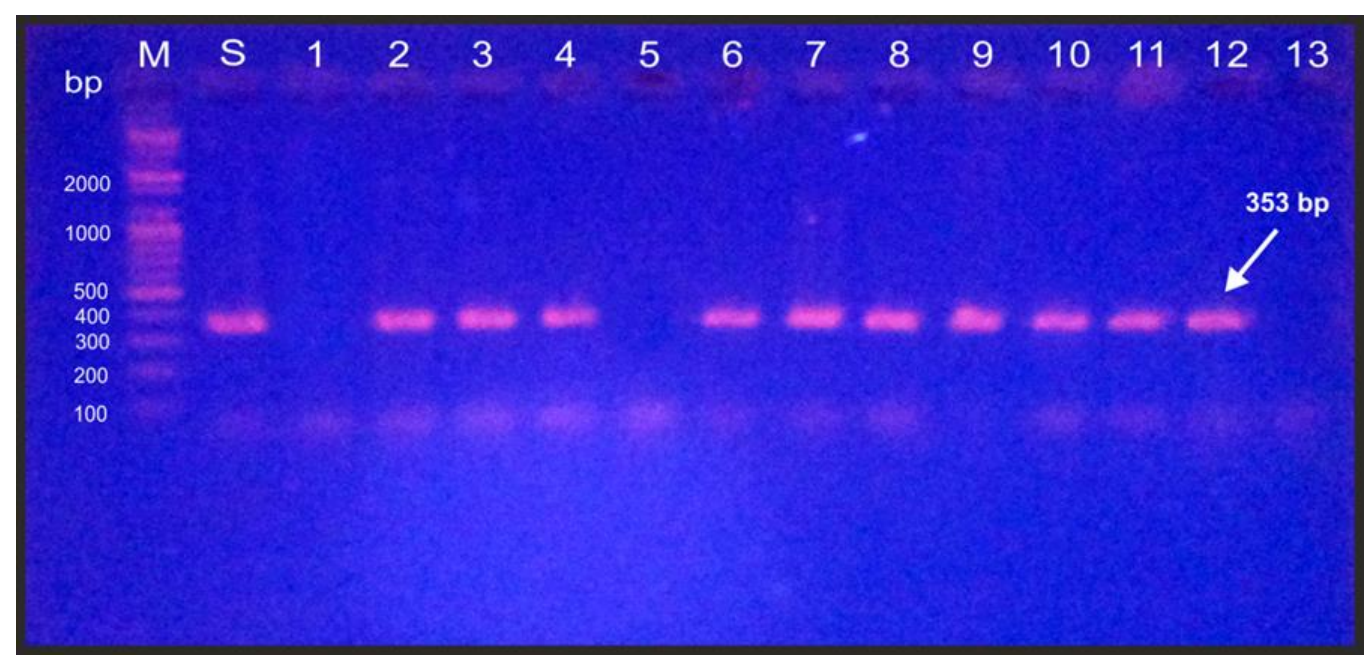

Figure 6. Gel electrophoresis for detection of bla $_{\text {oxa-51 like }}$ gene in A.baumannii isolates on agarose gel $2 \%$ and 50 volt for $60 \mathrm{~min}$. M:DNA ladder; S: standared strain. Isolates from 1-13

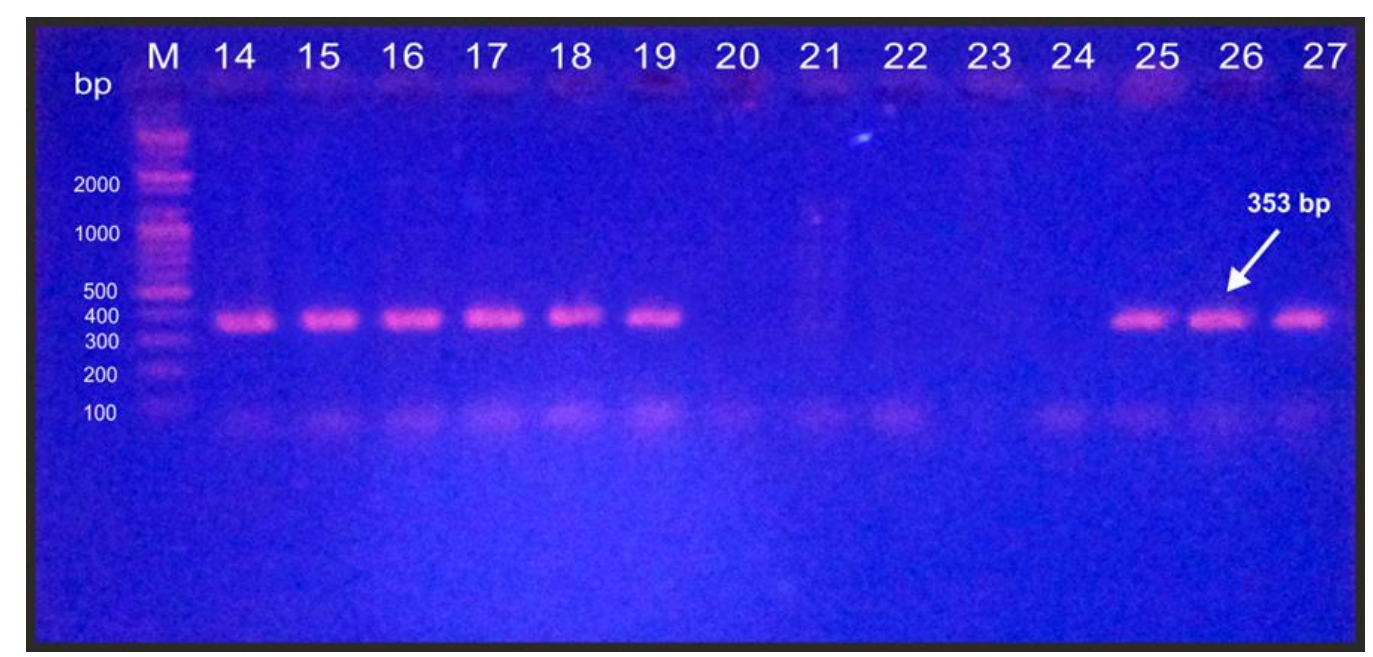

Figure 7. Gel electrophoresis for detection of bla $_{\text {oxa-51 like }}$ gene in A.baumannii isolates on agarose gel $2 \%$ and 50 volt for $60 \mathrm{~min}$. M:DNA ladder; S: standared strain. Isolates from 14-27. 
bla oxa-51 like gene is specific for A.baumannii species and is present on the chromosome (13). It is a diagnostic gene of $A$. baumannii but also has a significant role in resistance to antibiotics, because it is related to the resistance of carbapenem through the production of enzymes Carbapenemases, the secondary group of these enzymes is Class D carbapenem (oxa51), also called Oxacillinase naturally located on the chromosome of this bacteria $(14,15)$.

The percentage of $A$. baumannii isolated in our study was $8.1 \%$ (from 19 isolate of A.baumannii obtained from 233 sample), the isolates have been distributed between clinical (15) isolates and hospital environment (4) isolates (Table 1). Most isolates were from wound samples followed by respiratory tract infections, and none $A$. baumannii isolates were obtained from urine samples. The number of samples and geographical distribution of it may be the cause for different the ratio with other studies.

Table 2. Sample sources and the number of A.baumannii isolates.

\begin{tabular}{lcc}
\hline Sample source & $\begin{array}{l}\text { Total number } \\
\text { of sample }\end{array}$ & $\begin{array}{l}\text { Number of } \\
\text { A.baumannii } \\
\text { isolates }\end{array}$ \\
\hline Clinical Samples & 117 & $10(8.5 \%)$ \\
Wounds & 15 & $3(20 \%)$ \\
$\begin{array}{l}\text { Respiratory tract } \\
\text { infections }\end{array}$ & 8 & $1(12.5 \%)$ \\
Burns & 3 & $1(33.3 \%)$ \\
c.s.f & 23 & 0 \\
Urine & 17 & $2(11.7 \%)$ \\
Hospital environment & 23 & $1(4.3 \%)$ \\
Intensive care unit & 15 & $1(6.6 \%)$ \\
Patients bed & & 0 \\
$\begin{array}{l}\text { Devices and surgical } \\
\text { instruments }\end{array}$ & 5 & 0 \\
Incubators & 7 & $19(8.1 \%)$ \\
Emergency Lobby & 233 & \\
Total & &
\end{tabular}

The results of our study agreed with the study of (16) in Baghdad as the percentage of isolation of A.baumannii was $8.2 \%$ compared in the present study. Also, Al-Dulaimi et al. (17) in Babel obtained $7 \%$ percentage of A. baumannii isolates from wound infections. Isolation percentage in the current work was higher than the rate of isolation of Al Sehlawi et al. (18) in the city of Najaf in 2014, as it was $1.9 \%$ of the total samples of wounds, but less than the isolation rate of (19) in Iran 24\% isolation was obtained from respiratory infection.

\section{Presence of MDR and XDR for isolates A.baumannii}

For the purpose of determining which of our local isolates of A.baumannii belong to the MDR or XDR group, the sensitivity of the 19 bacterial isolates was first tested against 15 commonly used antibiotics. The diameter of the inhibition area was determined and compared with the tables of CLSI to determine resistance, sensitivity and moderate sensitivity (20).

Table 3 shows the ratio of sensitive isolates, resistance and average sensitivity in antibiotic susceptibility test. The results in Table (3) showed a high resistance of A.baumannii isolates to antibiotics, all 19 isolates were resistance 8 antibiotics(100\%), while $17 / 19$ isolates were resistance 3 antibiotics with the rate $(89.4 \%)$.

Table 3. Percentage of sensitive isolates, resistance and average sensitivity in antibiotic susceptibility test.

\begin{tabular}{cccc}
\hline Antibiotic & $\begin{array}{c}\text { Sensitive } \\
\% \text { isolates }\end{array}$ & $\begin{array}{c}\text { Modrate } \\
\text { isolates \% }\end{array}$ & $\begin{array}{c}\text { Resistance } \\
\text { isolates } \mid \%\end{array}$ \\
\hline $\begin{array}{c}\text { Ampicillin- } \\
\text { Sulbactam } \\
\text { Meropenem }\end{array}$ & $1(5.2 \%)$ & $\begin{array}{c}(52.6 \%) \\
10\end{array}$ & $8(42.1 \%)$ \\
Cefetriaxone & - & - & $19(100 \%)$ \\
Azithromycin & - & - & $19(100 \%)$ \\
Erythromycin & - & $2(10.5 \%)$ & $\begin{array}{c}(89.4 \%) \\
17\end{array}$ \\
Clarithromycin & $1(5.2 \%)$ & $1(5.2 \%)$ & $\begin{array}{c}(89.4 \%) \\
17\end{array}$ \\
Nalidixic acid & - & - & $19(100 \%)$ \\
Levofloxacine & - & $2(10.5 \%)$ & $(89.4 \%)$ \\
& & & $19(100 \%)$ \\
Ciprofloxacine & - & - & $19(100 \%)$ \\
Amikacin & - & - & $19(100 \%)$ \\
Gentamicin & - & - & $19(100 \%)$ \\
Tobramycin & - & - & $(78.9 \%)$ \\
Tetracycline & $2(10.5 \%)$ & $2(10.5 \%)$ & 15 \\
Doxycycline & $6(31.5 \%)$ & $1(5.2 \%)$ & $(63.1 \%)$ \\
& & & 12
\end{tabular}

A.baumannii bacteria have become important and a source of study by doctors and scientists because of the rapid spread of antibiotic resistance and the slow development of new antibiotics (21).

The results of our study were consistent with the study of AL-Kadmy et al. (22), It showed 100\% resistance of A.baumannii for Ciprofloxacine and Trimethoprime, the resistance to Cefetriaxone, Tobramycin, Tetracycline and B-lactams was more than $90 \%$.While the resistance to isolates of the antibiotic Meropenem is $86 \%$.This coincides with the results of the current study, which gave a100\% resistance to this antibiotic. 
Also, the results of our study were consistent with the results of the Azizi et al. (23) in terms of resistance to Ciprofloxacine and Gentamicin as it was $100 \%$ each of them.

When isolate was resistant to 3 classes of different antibiotics classified as MDR, the isolate was resistance of most antibiotics class except one or two groups classified as XDR

The results of our study showed 100\% MDR$\mathrm{Ab}$, and that MDR was known to be at least resistant to three classes of antibiotics, such as penicillins, cephalosporins, fluroquinolones, and aminoglycosides.

Sixteen isolates $(84.2 \%)$ of XDR-Ab were obtained, XDR is the isolating resistance of almost all antibiotic classes except one or two groups.

Our results matched the results of (24), with the MDR rate being $100 \%$, and the XDR ratio of our isolates was higher ( $62.8 \%$ ).

The MDR ratio was in agreement with that of (23).

The high resistance of isolates obtained in the present work may be due to several mechanisms: Aminoglycosides-modifying enzyme, Production of B-lactamases enzymes, Reduction in the expression of (altered) outer membrane proteins, Mutations in Topoisomerases, Work on increasing the organization of Efflux-pumps (25).

The results of the molecular diagnosis of bla oxa-51 gene confirmed the results of our study on MDR where all isolates had this gene, and that the results of this study confirmed that XDR-Ab is the largest antimicrobial antibiotic that must be treated and controlled in hospitals and health centers (6)

\section{Conclusion:}

A.baumannii can grow on simple culture media prepared in the laboratory (nonfastidious).

It was called the term "MDR" and "XDR" because of its resistance to many antibiotics, as well as its possession of antibiotic-resistant genes such as a gene bla oxA 51-like which is a fundamental gene for the diagnosis of this type of bacteria.

\section{Authors' declaration:}

- Conflicts of Interest: None.

- We hereby confirm that all the Figures and Tables in the manuscript are mine ours. Besides, the Figures and images, which are not mine ours, have been given the permission for republication attached with the manuscript.

- The author has signed an animal welfare statement.
- Ethical Clearance: The project was approved by the local ethical committee in University of Mosul.

\section{References:}

1. Doughari HJ, Ndakidem PA, Human IS, Benade S. The ecology, biology and pathogenesis of Acinetobacter spp.: an overview. Microbes Environ.2011; 26(2):101-112.

2. Lee CR, Lee JH, Park M, Park KS, Bae IK, Kim YB, et al Biology of Acinetobacter baumannii: pathogenesis, antibiotic resistance mechanisms, and prospective treatment options. Front Cell Infect Microbiol.2017;1(3): 7, 55.

3. Joly-Guillou ML. Clinical impact and pathogenicity of Acinetobacter. Clin Microbiol Infect.2005; 11(11): 868-873.

4. Gordon NC, Wareham DW. Multidrug-resistant Acinetobacter baumannii: mechanisms of virulence and resistance. Int $\mathbf{J}$ Antimicrob Agents.2010; 35(3): 219-226.

5. Darvishi M. Virulence factor Profile and Antimicrobial Resistance of Acinetobacter baumannii Strain isolated from various References 114 infection Recoverd from immunsuppressive patients.Biochem Pharmacol.2016; 9(3): 1057-10623.

6. Ece G, Erac B, Cetin H Y, Ece C, Baysak A. Antimicrobial susceptibility and clonal relation between Acinetobacter baumannii strains at a Tertiary Care Center in Turkey. Jundishapur J Microbiol.2015; 8(2):2-8.

7. Jawad A, Hawkey PM, Heritage J, Snelling AM. Description of Leeds Acinetobacter Medium, a new selective and differential medium for isolation of clinically important Acinetobacter spp., and comparison with Herellea agar and Holton's agar. J. Clin. Microbiol..1994;32(10): 2353-2358.

8. Atlas RM. Handbook of microbiological media 4th ed. LCC: Taylor and Francis Group; 2010. 821 p.

9. Leboffe MJ, Pierce BE. A Photographic Atlas for the Microbiology labrartory 4th ed. Morton Publishing Company;2011. P.71-98.

10. Brown A. Smith H. Benson's Microbiological Applications: laboratory manual in general microbiology, short version. 13th ed. McGraw-Hill Education.2015. P.257-261.

11. Li P, Li H, Lei H, Liu W, Zhao X, Guo L, et al. Rapid detection of Acinetobacter baumannii and molecular epidemiology of carbapenem-resistant $A$. baumannii in two comprehensive hospitals of Beijing, China. Front Microbiol.2015; 6(1) : 6, 997.

12. McConnell MJ, Pérez-Ordóñez A, Pérez-Romero P, Valencia R, Lepe JA, Vázquez-Barba I, et al. Quantitative real-time PCR for the detection of Acinetobacter baumannii colonization in the hospital environment. . J. Clin. Microbiol... 2012;1(4):0656611 .

13. Jorgensen JH, Hindler JF, Reller LB, Weinstein MP. New consensus guidelines from the Clinical and Laboratory Standards Institute for antimicrobial susceptibility testing of infrequently isolated or 
fastidious bacteria.Clin Infect Dis. 2007; 44(2): 280286.

14. Vali L, Dashti K, Opazo-Capurro A F, Dashti AA, Al Obaid K, Evans BA. Diversity of multi-drug resistant Acinetobacter baumannii population in a major hospital in Kuwait. Front Microbiol.2015;743(6):72-76.

15. Nowak P, Paluchowska P, Budak A. Distribution of blaoxa genes among carbapenem-resistant Acinetobacter baumannii nosocomial strains in Poland. New Microbial.2012; 35: 317-325.

16. Al-Dulaimi AA, Al-Taai HR, Al-Bajlany SM. Virulence Factors of Acinetobacter baumannii isolated from different clinical specimens in Baquba. DJPS.2017;13(1): 13-26.

17. AL Mahdi ZA, Bunyan IA, AL Shukri MS. Molecular study for some virulence factors of acinetobacter baumannii isolated from patients with wound infection in hilla city. World J Pharm Res, 2016; 5(3): 175-187.

18. Al Sehlawi ZS, Al Mohana AM, Al Thahab AA. Isolation and identification of Acinetobacter baumannii clinical isolates using novel methods. JUBPAS, 2014; 22(3): 1041-1050.

19. Babapour E, Haddadi A, Mirnejad R, Angaji SA, Amirmozafari N. Biofilm formation in clinical isolates of nosocomial Acinetobacter baumannii and its relationship with multidrug resistance. Asian Pac J Trop Biomed.2016A; 6(6): 528-533
20. Clinical Laboratory Standards Institute (CLSI). Performance standards for antimicrobial susceptibility testing twenty-six informational supplement. Pennsylvania: Clinical Laboratory Standards Institute.2016.Chapter 36. PP. 66-67.

21. Bialvaei AZ, Samadi KH. Colistin, mechanisms and prevalence of resistance. Curr Med Res Opin.2015; 31(4):707-721.

22. AL-Kadmy IM, Ali AN, Salman IM, Khazaal SS. Molecular characterization of Acinetobacter baumannii isolated from Iraqi hospital environment.New Microbes New Infect. 2018; 21: 51-57.

23. Azizi O, Shahcheraghi F, Salimizand H, Modarresi F, Shakibaie MR, Mansouri S, et al. Molecular analysis and expression of bap gene in biofilm-forming multidrug-resistant Acinetobacter baumannii. .Rep Biochem Mol Biol.2016; 5(1): 62.

24. Fazeli H, Taraghian A, Kamali R, Poursina F, Esfahani, BN, Moghim S. Molecular identification and antimicrobial resistance profile of Acinetobacter baumannii isolated from nosocomial infections of a teaching hospital in Isfahan, IranAvicenna J Clin Microbiol Infect.2014; 1(3).

25. Shehata AI. Phenotypic and genotypic typing of Multidrug-Resistant Acinetobacter baumannii by plasmid profiles and Multiplex-PCR typing. Sci. J. Microbiol. 2012;3(2):7.

\title{
تثخيص بكتريا Acinetobacter baumannii وتحديد عزلات الـ MDR و وXDR
}

$$
\text { غادة عبد الرزاق محمد }
$$

\author{
نور حسين احمد 1 \\ 1 قسم تقنيات المختبرات الطبية، كلية النور الجامعة، نينوى، العراق. \\ 20 قسم علوم الحياة، كلية العلوم، جامعة الموصل، النور الموصل، العراق.
}

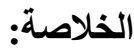

ركزت الدر اسة الحالية على بكتريا Acinetobacter baumannii بسبب أهميتها كمصدر للإصابة بعدوى المستشفيات فضلا عن

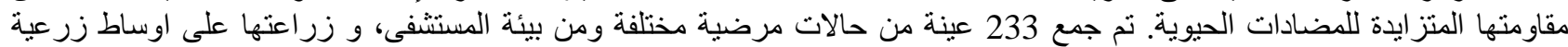

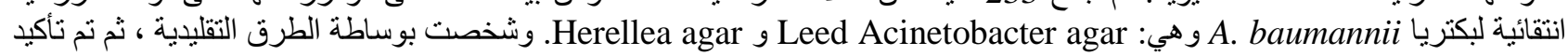

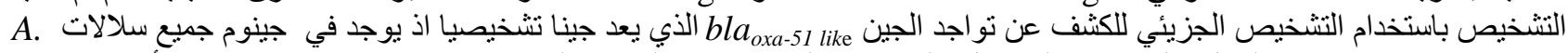
أسumannii

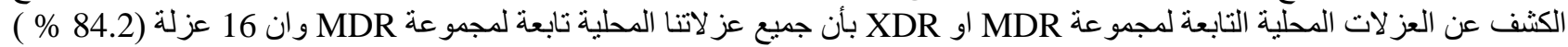

هDR هي

الكلمات المفتاحية: MDR ،MDR ، bla oxa5llikegene ، Acinetobacter baumannii. 